\title{
A report on the occurrence of accessory triradii in the subdigital area, and carpal triradii on the palm in Polish and Czech populations
}

\author{
Adam Gasiorowski ${ }^{1}$, Václav Hajn ${ }^{2}$ \\ ${ }^{1}$ Department of Archaeology, Maria Curie-Skłodowska University, \\ pl. M. Curie-Skłodowskiej 4, 20-031 Lublin, Poland \\ ${ }^{2}$ Department of Zoology and Anthropology, Palacký University, \\ tř. Svobody 26, 77146 Olomouc, Czech Republic
}

\begin{abstract}
The study analyses the occurrence of accessory triradii and carpal triradii on human palms in two populations. Accessory triradii were observed in Polish and Czech populations very rarely (triradius $d^{\prime}$ was most frequent). The occurrence of the abortive main line $C(Y)$ was observed more often in the Polish population and it was a statistically significant difference. A very high symmetry was stated between the occurrence of forms $C(Y)$ and $c(X)$ on right and left palms. A higher frequency of occurrence was stated in the case of carpal triradius $t$ in the Polish population and of triradius $t^{\prime}$ in the Czech population. However, the differences are not statistically significant.
\end{abstract}

KEY WORDS dermatoglyphics, carpal triradii, accessory triradii

Prz. Antropol. - Anthropol. Rev. (2000), vol. 63, pp. 127-132, Tables 7. ISBN 83-8696960-1, ISSN 0033-2003

Similarly to other anthropological features, the arrangement of skin ridges on palms is characterized by a considerable variability between individuals. The rhythm of this changeability may be disturbed as a result of corrupt genetic and non-genetic factors operating in the early phase of fetal development. The presence of a loop is always connected with the presence of a triradius. With the absence of a loop and the regular number of fingers, the minimum number of triradii cannot be smaller than 4 in the subdigital area. In some cases one of the subdigital triradii may be replaced by a zygodactylic triradius. The presence of one of these triradii, $z, z^{\prime}$ or $z^{\prime \prime}$, may also cause an absence of an appropriate triradius in the subdigital area. The number of subdigital triradii may be diminished in the

\footnotetext{
* The study was undertaken as a result of the co-operation project between the Department of Zoology and Anthropology, University of Olomouc, and the Department of Archeology, Maria Curie-Skłodowska University in Lublin.
} 


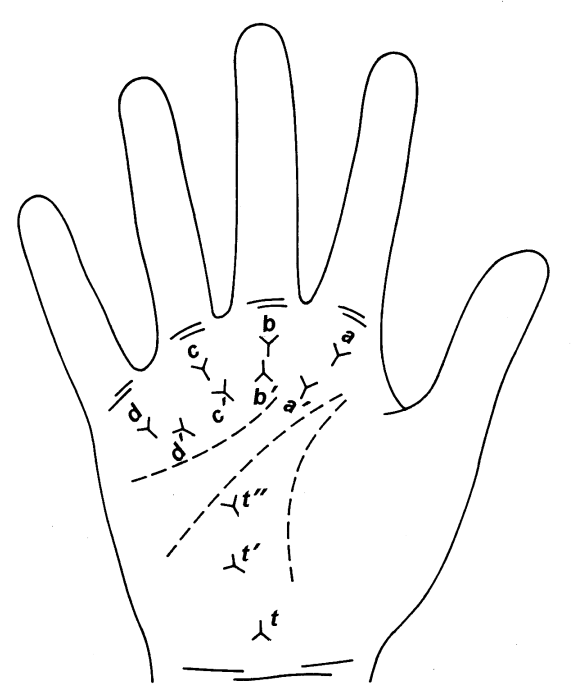

Fig. 1. Triradii on the palm: $a, b, c, d$-digital; $a^{\prime}, b^{\prime}, c^{\prime}$, $d^{\prime}$ - accessory digital; $t, t^{\prime}, t^{\prime \prime}$ - axial (carpal) ones.

case of the presence of the axial triradius $t$ or of its variants $t^{\prime}$ and $t^{\prime \prime}$. Obviously, the presence of loops in the pattern of palm dermatoglyphics is connected with an increase in the number of triradii.

The aim of this report was to present the frequency of occurrence of accessory triradii in the subdigital area, and of axial triradii in Polish and Czech populations (Figure 1).

\section{Materials and methods}

The material consisted of the prints of palms of 200 men and 200 women from Lublin (Poland) and of 200 men and 200 women from Olomouc (Czech Republic). The prints were made by the method adopted from finger printing and examined by the methods worked out by CUMMINS \& MIDLO [1961], and VALŠíK [1928].

The abortive main line $C$ was denoted by $Y$ while the absence of a triradius $c$ was denoted as $X$. These denotations were first employed by J. Valšík and published in the presentation of his method in 1928. In the case when in one palm of one person there occurred together accessory triradii $a^{\prime}$ and $d^{\prime}$, they were denoted as $a^{\prime} d^{\prime}$. Letter $O$ was used to denote those cases when in one palm there was no accessory triradius but it occurred in the other palm.

\section{Results and discussion}

\section{Triradii in the subdigital area}

The occurrence of triradii in men and women on left and right palms in Polish and Czech populations has been presented in Table 1. In both populations and both sexes, the most frequent was the occurrence of the accessory triradius $d^{\prime}$; in men and women it was always more frequent on the left palm in both populations. POSPIŠIL [1959] and HAJN [1964] obtained similar results in Czech population. Accessory triradii $b^{\prime}$ and $c^{\prime}$ occurred very rarely, whereas triradii $a^{\prime}$ appeared in about $4 \%$ of both Polish and Czech populations; it was always more frequent in the right palm in both sexes and in both populations. These results are in agreement with those published by HOLOMEK [1948], POSPIŠIL [1959] and HAJN [1964].

The symmetry of the occurrence of accessory triradii in both hands in men and women from Lublin is shown in Table 2.

Table 3 of this report illustrates the occurrence of the abortive main line $C(Y)$ and absence of triradius $c(X)$ in both groups. In the Czech population in men and women, on both hands, the frequency is lower than that in the Polish population (in Czechs it is $11.0 \%$ on the left hand in 
Table 1. The occurrence of accessory triradii (in \%) on palms

\begin{tabular}{|c|c|c|c|c|c|c|c|c|}
\hline & \multicolumn{4}{|c|}{ LUBLIN } & \multicolumn{4}{|c|}{ OLOMOUC } \\
\hline & \multicolumn{2}{|c|}{ Men } & \multicolumn{2}{|c|}{ Woman } & \multicolumn{2}{|c|}{ Men } & \multicolumn{2}{|c|}{ Woman } \\
\hline & left & right & left & right & left & right & left & right \\
\hline$a^{\prime}$ & 2.00 & 6.00 & 1.50 & 6.50 & 2.50 & 5.00 & 2.00 & 7.00 \\
\hline$b^{\prime}$ & - & - & - & - & - & 0.50 & - & 0.50 \\
\hline$c^{\prime}$ & - & 0.50 & 1.50 & 0.50 & 0.50 & - & - & - \\
\hline$d^{\prime}$ & 18.50 & 14.00 & 16.50 & 13.50 & 14.00 & 8.00 & 20.00 & 13.50 \\
\hline
\end{tabular}

Table 2. Symmetry in the occurrence of accessory triradii (in \%) on palms of men and women from Lublin

\begin{tabular}{|c|c|c|c|c|c|c|c|}
\hline left $\quad$ right & $a^{\prime}$ & $\overline{b^{\prime}}$ & $c^{\prime}$ & $d^{\prime}$ & 0 & $a^{\prime} d^{\prime}$ & $\Sigma$ \\
\hline \multicolumn{8}{|c|}{ MEN } \\
\hline $\begin{array}{l}a^{\prime} \\
b^{\prime} \\
c^{\prime}\end{array}$ & 1.00 & & & & & 0.50 & $\begin{array}{l}1.50 \\
- \\
-\end{array}$ \\
\hline$d^{\prime}$ & & & 0.50 & 8.00 & 8.00 & 1.50 & 18.00 \\
\hline 0 & 2.00 & & & 3.00 & 74.50 & 0.50 & 80.00 \\
\hline$a^{\prime} d^{\prime}$ & & & & & & 0.50 & 0.50 \\
\hline$\Sigma$ & 3.00 & - & 0.50 & 11.00 & 82.50 & 3.00 & 100.00 \\
\hline \multicolumn{8}{|c|}{ WOMEN } \\
\hline $\begin{array}{l}a^{\prime} \\
b^{\prime}\end{array}$ & & & & & 0.50 & & $\begin{array}{l}0.50 \\
-\end{array}$ \\
\hline$c^{\prime}$ & & & 0.50 & & 1.00 & & 1.50 \\
\hline$d^{\prime}$ & 1.50 & & & 7.50 & 4.50 & 2.00 & 15.50 \\
\hline 0 & 2.00 & & & 3.50 & 76.00 & & 81.50 \\
\hline$a^{\prime} d^{\prime}$ & 0.50 & & & & & 0.50 & 1.00 \\
\hline$\Sigma$ & 4.00 & - & 0.50 & 11.00 & 82.00 & 2.50 & 100.00 \\
\hline
\end{tabular}

Table 3. The occurrence of triradii $c(X)$ and the abortive main line $C(Y)$ on left and right palms of men and women from Lublin and Olomouc

\begin{tabular}{rrrrrrrrr}
\hline & & \multicolumn{2}{c}{ Men } & \multicolumn{2}{c}{ left } & \multicolumn{2}{c}{ light } & \multicolumn{3}{c}{ left } & \multicolumn{2}{c}{ right } \\
\hline & $N$ & $\%$ & $N$ & $\%$ & $N$ & $\%$ & $N$ & $\%$ \\
\hline & & & & LUBLIN & & & & \\
$Y$ & 44 & 22.0 & 22 & 11.0 & 44 & 22.0 & 20 & 10.0 \\
$X$ & 25 & 12.5 & 16 & 8.0 & 24 & 12.0 & 13 & 6.5 \\
& & & & OLOMOUC & & & & \\
$Y$ & 22 & 11.0 & 13 & 6.5 & 19 & 9.5 & 12 & 6.0 \\
$X$ & 12 & 6.0 & 5 & 2.5 & 15 & 7.5 & 7 & 3.5 \\
\hline
\end{tabular}

men and $9.5 \%$ in women; in Poles it is $22.0 \%$ in each sex). Statistically significant differences occur only in the case of the abortive main line $C(Y)$. Examining a rural group from the Lublin region, HAJN \& GĄSIOROWSKI [1999] observed lower values of the occurrence of form $C(Y)$, namely: in men $17.0 \%$ on the left hand and $14.5 \%$ on the right hand, while in women it was $14.0 \%$ on the left hand and $3.0 \%$ on the right hand. These results are closer to the Czech population. 
Table 4. Symmetry in the occurrence of $c(X)$ and $C(Y)$ on palms of men and women from Lublin

\begin{tabular}{|c|c|c|c|c|c|}
\hline left $>$ right & $Y$ & $x$ & 0 & $\Sigma$ & $\%$ \\
\hline \multicolumn{6}{|c|}{ MEN } \\
\hline$Y$ & 13 & 3 & 28 & 44 & 22.0 \\
\hline$x$ & 2 & 11 & 12 & 25 & 12.5 \\
\hline 0 & 7 & 2 & 122 & 131 & 65.5 \\
\hline$\Sigma$ & 22 & 16 & 162 & 200 & 100.0 \\
\hline$\%$ & 11.0 & 8.0 & 81.0 & 100.0 & \\
\hline \multicolumn{6}{|c|}{ WOMEN } \\
\hline$Y$ & 13 & - & 31 & 44 & 22.0 \\
\hline$X$ & - & 11 & 13 & 24 & 12.0 \\
\hline 0 & 7 & 2 & 123 & 132 & 66.0 \\
\hline$\Sigma$ & 20 & 13 & 167 & 200 & 100.0 \\
\hline$\%$ & 10.0 & 6.5 & 83.5 & 100.0 & \\
\hline
\end{tabular}

Table 4 summarizes the symmetry in the occurrence of forms $C(Y)$ and $c(X)$ between left and right hands in men and women in the Polish population. The accumulation of higher values along the diagonal from the left upper corner towards the right lower corner indicates very high symmetry.

\section{Carpal triradii}

In men from Lublin, triradius $t^{\prime}$ occurs on the left hand in $71 \%$ and on the right hand in $65 \%$, while in women from Lublin the pattern occurs on the left hand in $66.5 \%$ and on the right hand in $61.5 \%$ (Table 5). The pattern next in respect to the frequency of occurrence is triradius $t^{\prime}$ which appeared in $12.0 \%$ on the left hand and $11.0 \%$ on the right hand in Polish men, and in $16.0 \%$ on both hands in Polish women. In the Polish population the frequency of occurrence of triradius $t^{\prime \prime}$ is from $2.5 \%$ to $4.5 \%$. All these triradii may form a number of combinations on one palm. The most frequent are the $\mathrm{tt}^{\prime}$ (7.25\%) and $t t^{\prime \prime}(5.0 \%)$ combinations on both palms.
In the Czech population (Table 6) triradius $t$ is also the most frequent form; it appeared in men in $68.5 \%$ on the left palm and in $63.0 \%$ on the right palm, while in women it was found in $67.0 \%$ on the left palm and in $58.0 \%$ on the right palm. Other authors [MALÁ 1961; POSPIŠIL 1962; HAJN 1964; BENEŠ \& INDROVÁ 1973] confirm the Czech results. In men triradius $t^{\prime}$ occurred in $16.0 \%$ on the left hand and in $17.0 \%$ on the right hand, while in women it appeared in $17.5 \%$ on the left hand and in $22.0 \%$ on the right palm. In men triradius $t^{\prime \prime}$ appeared in $2.75 \%$ and in women in $3.75 \%$. The most frequent types of triradial combinations were $t t^{\prime}$ (in men $4.75 \%$ and in women $4.50 \%)$ and $t t^{\prime \prime}(8.0 \%$ in men and $4.25 \%$ in women). Other combinations were numerically close to those in the Polish population.

While comparing Poles and Czechs it has been found that in the former, in both sexes, there appeared a higher frequency of $t^{\prime}$ triradii, whereas triradius $t^{\prime}$ occurred most frequently in Czechs. The differences between the populations were not statistically significant. The 
Table 5. The occurrence of carpal triradii on palms in the Polish population (Lublin)

\begin{tabular}{|c|c|c|c|c|c|c|c|c|}
\hline & \multicolumn{4}{|c|}{ MEN } & \multicolumn{4}{|c|}{ WOMEN } \\
\hline & \multicolumn{2}{|c|}{ left } & \multicolumn{2}{|c|}{ right } & \multicolumn{2}{|c|}{ left } & \multicolumn{2}{|c|}{ right } \\
\hline & $N$ & $\%$ & $N$ & $\%$ & $N$ & $\%$ & $N$ & $\%$ \\
\hline $\bar{t}$ & 142 & 71.00 & 130 & 65.00 & 133 & 66.50 & 123 & 61.50 \\
\hline$t^{\prime}$ & 24 & 12.00 & 22 & 11.00 & 32 & 16.00 & 32 & 16.00 \\
\hline$t^{\prime \prime}$ & 9 & 4.50 & 9 & 4.50 & 5 & 2.50 & 7 & 3.50 \\
\hline$t t$ & 1 & 0.50 & 4 & 2.00 & 1 & 0.50 & 2 & 1.00 \\
\hline$t t^{\prime}$ & 13 & 6.50 & 16 & 8.00 & 15 & 7.50 & 14 & 7.00 \\
\hline$t t^{\prime \prime}$ & 9 & 4.50 & 11 & 5.50 & 10 & 5.00 & 13 & 6.50 \\
\hline$t^{\prime} t^{\prime \prime}$ & 1 & 0.50 & - & - & 2 & 1.00 & 1 & 0.50 \\
\hline$t t^{\prime \prime} t^{\prime \prime}$ & 1 & 0.50 & - & - & - & - & - & - \\
\hline 0 & - & - & 8 & 4.00 & 2 & 1.50 & 8 & 4.00 \\
\hline$\Sigma$ & 200 & 100.00 & 200 & 100.00 & 200 & 100.00 & 200 & 100.00 \\
\hline
\end{tabular}

Table 6. The occurrence of carpal triradii on palms in the Czech population (Olomouc)

\begin{tabular}{l|rrrr|rrrr}
\hline & \multicolumn{2}{|c}{ left } & \multicolumn{3}{c|}{ MEN } & \multicolumn{2}{c}{ right } & \multicolumn{3}{c}{ left } & \multicolumn{3}{c}{ WOMEN } \\
& $N$ & \multicolumn{1}{c}{$\%$} & $N$ & $\%$ & $N$ & \multicolumn{1}{c}{ right } \\
\hline$t$ & 137 & 68.50 & 126 & 63.00 & 134 & 67.00 & 116 & 58.00 \\
$t^{\prime}$ & 32 & 16.00 & 34 & 17.00 & 35 & 17.50 & 44 & 22.00 \\
$t^{\prime \prime}$ & 6 & 3.00 & 5 & 2.50 & 8 & 4.00 & 7 & 3.50 \\
$t t$ & 1 & 0.50 & 2 & 1.00 & 1 & 0.50 & 4 & 2.00 \\
$t t^{\prime}$ & 8 & 4.00 & 11 & 5.50 & 9 & 4.50 & 9 & 4.50 \\
$t t^{\prime \prime}$ & 15 & 7.50 & 17 & 8.50 & 6 & 3.00 & 11 & 5.50 \\
$t^{\prime} t^{\prime}$ & 1 & 0.50 & 1 & 0.50 & 1 & 0.50 & 1 & 0.50 \\
$t^{\prime} t^{\prime \prime}$ & - & - & 1 & 0.50 & 4 & 2.00 & 2 & 1.00 \\
$t t t^{\prime}$ & - & - & - & - & - & - & 1 & 0.50 \\
$t t t^{\prime \prime}$ & - & - & - & - & - & - & 1 & 0.50 \\
$t t^{\prime} t^{\prime \prime}$ & - & - & 1 & 0.50 & 2 & 1.00 & - & - \\
$O$ & - & - & 2 & 1.00 & - & - & 4 & 2.00 \\
$\Sigma$ & 200 & 100.00 & 200 & 100.00 & 200 & 100.00 & 200 & 100.00 \\
\hline
\end{tabular}

differences of the other triradii were similar and greater differences were observed in cases of triradius absence (denoted by $O$ ): in Polish men and women it occurred in $4 \%$ on the right palm and in Czech men it was $1 \%$ while in Czech women it was $2 \%$. The Czech population revealed the co-occurrence of triradii on one palm in the form of such combinations as $t^{\prime} t^{\prime}, t t t^{\prime}$ and $t t t$ in less than $1 \%$, with the absence of such combinations in the Polish population. Generally speaking, one may state that the number of triradii in the carpal region shows no great differences between these populations.

The next section of this report discusses the symmetry between the right and left palms for triradii and their combinations for the Polish population (Table 7). The grouping of higher values on the diagonals from the upper left corner to lower right corner of the table proves a very high co-occurrence of the same patterns or their combinations on both left and right palms. The symmetry is characteristic of both sexes. In men it is higher than in women in the case of triradii $t$ and $t^{\prime}$. 
Table 7. Symmetry in the occurrence of carpal triradii (in \%) between left and right palms in men and women from Lublin

\begin{tabular}{|c|c|c|c|c|c|c|c|c|c|c|}
\hline left right & $\bar{t}$ & $t^{\prime}$ & $t^{\prime \prime}$ & $t t$ & $t t^{\prime}$ & $t t^{\prime \prime}$ & $t^{\prime} t^{\prime \prime}$ & $t t^{\prime} t^{\prime \prime}$ & 0 & $\Sigma$ \\
\hline \multicolumn{11}{|c|}{ MEN } \\
\hline $\bar{t}$ & 59.5 & 5.0 & & 1.5 & 2.5 & 0.5 & & & 2.0 & 71.0 \\
\hline$t^{\prime}$ & 2.0 & 5.5 & 1.5 & 0.5 & 0.5 & 0.5 & & & 1.5 & 12.0 \\
\hline$t^{\prime \prime}$ & & 0.5 & 3.0 & & & 1.0 & & & & 4.5 \\
\hline$t t$ & 0.5 & & & & & & & & & 0.5 \\
\hline$t t^{\prime}$ & 2.5 & & & & 4.0 & & & & & 6.5 \\
\hline$t t^{\prime \prime}$ & 0.5 & & & & 0.5 & 3.0 & & & 0.5 & 4.5 \\
\hline$t^{\prime} t^{\prime \prime}$ & & & & & & 0.5 & & & & 0.5 \\
\hline$t t^{\prime} t^{\prime \prime}$ & & & & & 0.5 & & & & & 0.5 \\
\hline 0 & & & & & & & & & & - \\
\hline$\Sigma$ & 65.0 & 11.0 & 4.5 & 2.0 & 8.0 & 5.5 & - & - & 4.0 & 100.0 \\
\hline \multicolumn{11}{|c|}{ WOMEN } \\
\hline$t$ & 54.0 & 4.0 & 1.0 & 1.0 & 2.0 & 2.5 & & & 2.0 & 66.5 \\
\hline$t^{\prime}$ & 3.0 & 11.5 & 0.5 & & 0.5 & & & & 0.5 & 16.0 \\
\hline$t^{\prime \prime}$ & & & 2.0 & & 0.5 & & & & & 2.5 \\
\hline$t t$ & 0.5 & & & & & & & & & 0.5 \\
\hline$t t^{\prime}$ & 2.0 & 0.5 & & & 4.0 & 0.5 & & & 0.5 & 7.5 \\
\hline$t t^{\prime \prime}$ & 1.5 & & & & & 3.0 & & & 0.5 & 5.0 \\
\hline$t^{\prime} t^{\prime \prime}$ & & & & & & 0.5 & 0.5 & & & 1.0 \\
\hline$t t^{\prime} t^{\prime \prime}$ & & & & & & & & & & - \\
\hline 0 & 0.5 & & & & & & & & 0.5 & 1.0 \\
\hline$\Sigma$ & 61.5 & 16.0 & 3.5 & 1.0 & 7.0 & 6.5 & 0.5 & - & 4.0 & 100.0 \\
\hline
\end{tabular}

\section{References}

Beneš J., O. InDROVÁ, 1973, Palm dermatoglypics of the Czechs from the South Moravian region (Czechoslovakia), Anthropologie, XI, 71-75

Cummins H., C. MidLo, 1961, Finger Prints, Palms and Soles: An Introduction to Dermatoglyphics, Dover Publ. Inc, New York

HaJN V., 1964, Príspěvek $k$ dermatoglyfice olomoucké mládeže, PřF UP Olomouc, Diplomová práce, pp. 64

HAJN V., A. GASIOROWSKI, 1999, The terminations of the main lines on human hands in Polish and Czech populations [in:] Człowiek wczoraj, dzis, jutro, Wyd. UMCS, Lublin, pp. 287-294

HolOMeK A., 1948, Palmární dermatoglyfy moravské, Zpr. Anthrop. Společ., 1 (5), 5-7

MALÁ L., 1961, Dermatoglyfy na otiscich prstů $u \check{C}$ echü, Antrop. Archiv., Praha, pp. 43-56

PosPišíl M.F., 1959, Dermatoglyfika Hlučiňanů. Dermatoglyfické útvary dlaně, Acta F.R.N. Univ. Comen., III, 5-8, Anthropologia, 361-383 Pospišíl M.F., 1962, Dermatoglyfika Slovenska, Kand. diz. práca, Bratislava, pp. 267

VALŠík I.A., 1928, Pokus o nové vyjádřeni formuli papilárnich linii lidské dlané, Čas. Lék. Čes., 67 (8), 37-43

\section{Streszczenie}

Doniesienie dotyczy występowania trójpromieni dodatkowych i karpalnych na dłoni człowieka w populacji polskiej i czeskiej. Występowanie dodatkowych trójpromieni w obu populacjach obserwowano bardzo rzadko. Trójpromień $a^{\prime}$ pojawił w około 4\% przypadków, częściej na prawej dłoni, u obu płci, w obu populacjach. Trójpromień $d^{\prime}$ spotykano częściej. Występowanie skróconej linii głównej $C(Y)$ obserwowano częściej w populacji polskiej i była to różnica statystycznie istotna. Bardzo wysoką symetrię odnotowano między występowaniem form $C(Y)$ i $c(X)$ na prawej i lewej dłoni.

Stwierdzono wysoką częstotliwość występowania trójpromienia $t$ w populacji polskiej i trójpromienia $t^{\prime} \mathrm{w}$ populacji czeskiej. Różnice te nie były jednak statystycznie istotne. Badanie wykazało również bardzo wysoką symetrię między prawą i lewą dłonią w populacji polskiej. 